\title{
Electrochemical Characterization of Patinas Formed on a Historic Bell from the Cathedral Museum of Campeche-México, World Heritage Site
}

\author{
D. E. Arceo-Gómez ${ }^{1}$, J. Reyes-Trujeque ${ }^{1}$, G. E. Zambrano-Rengel ${ }^{1,2}$, T. Pérez-López ${ }^{1}$, \\ R. Orozco-Cruz,* \\ ${ }^{1}$ Centro de Investigación en Corrosión. Universidad Autónoma de Campeche. Campus 6 de \\ Investigaciones. C.P. 24070. San Francisco de Campeche, Campeche, México. \\ ${ }^{2}$ Programa Cátedras CONACyT. Av. Insurgentes Sur 1582, Col. Crédito Constructor. Delegación \\ Benito Juárez. C.P. 03940. Ciudad de México, México. \\ ${ }^{3}$ Instituto de Ingeniería. Universidad Veracruzana. Av. S.S. Juan Pablo II. Zona Universitaria. C.P. \\ 94294. Boca del Río, Veracruz, México. \\ *E-mail: rorozco@uv.mx
}

doi: $10.20964 / 2016.11 .34$

Received: 10 August 2016 / Accepted: 5 September 2016 / Published: 10 October 2016

The Cathedral of Nuestra Señora de la Inmaculada Concepción, from the historical City of San Francisco de Campeche (México), is considered one of the most important Novo Hispanic Baroque buildings constructed between 1650 and 1760 by the Spanish colonizers in the South East of the country. Actually the Cathedral is part of about 1500 constructions included into the UNESCO's Cultural Heritage awarded by the City in 1999. Its Diocesan Museum of Sacred Art has a significant collection of invaluable historic artifacts from colonial period, such a bronze bell dating from 1650 . This study was carried out in order to evaluate the electrochemical behavior of natural patinas formed over the bell surface by using Electrochemical Impedance Spectroscopy (EIS). In situ test under simulated acid rain media and complementary surface analysis such SEM/EDS, XRD and metallography allowed an assessment of the behavior of this ancient bronze bell under atmospheric incidences along the time. The results suggest the closer interaction between metallic alloy composition, environmental conditions and the protective abilities of its patinas.

Keywords: bronze alloys, patinas, EIS, materials characterization, historic bell.

\section{$\underline{\text { FULL TEXT }}$}

(C) 2016 The Authors. Published by ESG (www.electrochemsci.org). This article is an open access article distributed under the terms and conditions of the Creative Commons Attribution license (http://creativecommons.org/licenses/by/4.0/). 